\author{
Marquette University \\ e-Publications@Marquette
}

\title{
Comment On "Patented Blunderings, Efficiency Awareness, And Self-Sustainability Claims in The Pyrolysis Energy from Waste Sector"
}

\author{
Patrick J. McNamara \\ Marquette University, patrick.mcnamara@marquette.edu \\ Daniel Zitomer \\ Marquette University, daniel.zitomer@marquette.edu \\ Zhongzhe Liu \\ Marquette University, zhongzhe.liu@marquette.edu
}

Follow this and additional works at: https://epublications.marquette.edu/civengin_fac

Part of the Civil Engineering Commons

\section{Recommended Citation}

McNamara, Patrick J.; Zitomer, Daniel; and Liu, Zhongzhe, "Comment On "Patented Blunderings, Efficiency Awareness, And Self-Sustainability Claims in The Pyrolysis Energy from Waste Sector"' (2019). Civil and Environmental Engineering Faculty Research and Publications. 227.

https://epublications.marquette.edu/civengin_fac/227 
Marquette University

\section{e-Publications@Marquette}

\section{Civil, Construction and Environmental Engineering Faculty Research and Publications/College of Engineering}

This paper is NOT THE PUBLISHED VERSION; but the author's final, peer-reviewed manuscript. The published version may be accessed by following the link in th citation below.

Resources, Conservation and Recycling, Vol. 143 (April 2019): 329-330. DOI. This article is (C) Elsevier and permission has been granted for this version to appear in e-Publications@Marquette. Elsevier does not grant permission for this article to be further copied/distributed or hosted elsewhere without the express permission from Elsevier.

\section{Comment On "Patented Blunderings, Efficiency Awareness, And Self-Sustainability Claims in The Pyrolysis Energy from Waste Sector"}

\section{Patrick McNamara}

Department of Civil, Construction and Environmental Engineering, Marquette University, Milwaukee, WI

Daniel Zitomer

Department of Civil, Construction and Environmental Engineering, Marquette University, Milwaukee, WI

Zhongzhe Liu

Department of Civil, Construction and Environmental Engineering, Marquette University, Milwaukee, WI 
waste (MSW) (Rollinson and Oladejo, 2019). However, the authors of the paper discuss an article that was written by the authors of this commentary on pyrolysis of wastewater biosolids. In the paper by Rollinson and Oladejo, it was noted that "consideration will also be given to sewage sludge, by definition a municipal solid waste, although invariably collected and managed separately." However, by definition, MSW is essentially "mixed household waste... (and) commercial waste...," and does not include sewage sludge (Vesilind et al., 2002). In fact, sewage is specifically excluded from the definition of solid waste in the US by the Resource Conservation and Recovery Act.

The context of our publication was municipal wastewater biosolids (treated sewage sludge), and we did not extrapolate our findings to MSW (McNamara et al., 2016). Rollinson and Oladejo (2019) recommend that pyrolysis should not be used for MSW because it is a net energy loss process and studies that claim otherwise ignored drying (Rollinson and Oladejo, 2019). In our 2016 publication, we stated "The enthalpy of pyrolysis is not a substantial energy cost compared to the energy requirements of biosolids drying." (McNamara et al., 2016). We note here that we should have used the phrase "enthalpy for pyrolysis" instead of "enthalpy of pyrolysis" since the energy required to raise biomass temperature as well as convert biomass into gas, liquid, and solid products was considered (Daugaard and Brown, 2003). Still, the enthalpy for pyrolysis is insignificant compared to the sensible and latent enthalpy of drying, which has implications for an industry that already dries biosolids for the reasons described below (McNamara et al., 2016).

We chose to exclude drying energy in our analysis of enthalpy for pyrolysis because we deemed it important to distinguish the energy cost of drying from the energy cost of pyrolysis for the wastewater industry for the following reasons. The Milwaukee Metropolitan Sewerage District (MMSD) and some other sanitary districts in the US have processed biosolids by heat-drying for as long as 100 years. The MMSD dried product, Milorganite ${ }^{\circledR}$, is employed across the US as a fertilizer and soil conditioner. There are energy costs associated with drying to produce Milorganite ${ }^{\bullet}$, and more Milorganite ${ }^{\oplus}$ is produced than is sold. Unsold Milorganite ${ }^{\bullet}$ is often given away or land applied. Unused Milroganite is rich in organic matter that has already been dried. The reason we conducted our pyrolysis energy balance on the dried biosolids was that the feedstock used for pyrolysis was biosolids that were already dried. For the wastewater utility, drying energy is often required whether or not the unused biosolids are subsequently pyrolyzed. We compared the energy required for pyrolysis to the energy required for drying. Therefore, our study was conducted to determine if pyrolysis for dried biosolids is a viable alternative to land application or landfilling. For the wastewater industry, it is practical to consider the energy balance of pyrolysis with drying energy outside the system boundary. We do agree with the authors that we made multiple assumptions for estimating the enthalpy for pyrolysis which resulted in large error bars for this value. Nevertheless, the energy costs of drying are far higher than the energy input for pyrolysis, indicating that, for an industry that already dries biosolids, pyrolysis could be used to recover energy from the dried biosolids in the form of pyrolysis gas (py-gas). As described in more detail in our publication, py-gas could be used to help offset energy costs associated with drying that has already taken place (McNamara et al., 2016). Pyrolysis of dried wastewater biosolids pertains to the wastewater industry, and may not be as relevant to municipal solid waste. The conclusion presented by Rollinson and Oladejo (2018) that, in many cases, pyrolysis may not practical, is more reasonable for cases in which waste products do not need to be dried.

We agree that tar production, co-combustion, and other practical issues need to be addressed during the scaleup of biosolids pyrolysis. While it is important to handle practical engineering issues and to provide fundamental theory, it is equally important to consider economic considerations such as revenue from products, provisions for public health, environmental protection and overall treatment costs. It is expensive to haul unused biosolids. Often dewatering processes are employed even though they require energy. In the case of wastewater in which i) solids continue to be produced by the public and need to be managed and ii) we already employ energyintensive processes such as activated sludge or dewatering, pyrolysis is one process to be considered as part of a 
utility's management plan to further protect public health and the environment. Biosolids pyrolysis also removes biological contaminants (Kimbell et al., 2018), destroys or removes micropollutants such as triclosan and triclocarban from solids (Ross et al., 2016; Hoffman et al., 2016), reduces dried solid mass for transport by approximately $60 \%$, and may concurrently result in some energy recovery from dried biosolids that may otherwise be wasted (McNamara et al., 2014; Liu et al., 2018). Moreover, biochar is a possible value-added product (Carey et al., 2015), and the value of biochar may offset some production costs. In addition, new autocatalytic pyrolysis processes have been developed to reduce tar production and increase py-gas production (Liu et al., 2016a, 므; Liu et al., 2017). Therefore, wastewater pyrolysis should continue to be investigated for biosolids management.

\section{References}

Carey et al., 2015 D.E. Carey, P.J. McNamara, D.H. Zitomer Biochar from pyrolysis of biosolids for nutrient adsorption and turfgrass cultivation Water Environ. Res., 87 (12) (2015), pp. 2098-2106

Daugaard and Brown, 2003 D.E. Daugaard, R.C. Brown Enthalpy for pyrolysis for several types of biomass Energy Fuels, 17 (4) (2003), pp. 934-939

Hoffman et al., 2016 T.C. Hoffman, D.H. Zitomer, P.J. McNamara Pyrolysis of wastewater biosolids significantly reduces estrogenicity J. Hazard. Mater., 317 (2016), pp. 579-584

Kimbell et al., 2018 L.K. Kimbell, A.D. Kappell, P.J. McNamara Effect of pyrolysis on the removal of antibiotic resistance genes and class 1 integrons from municipal wastewater biosolids Environ. Sci. Water Res. Technol., 4 (2018), pp. 1807-1818

Liu et al., 2016a Z. Liu, P. McNamara, D. Zitomer Product upgrading during biosolids pyrolysis by using a lowcost natural catalyst Proc. Water Environ. Fed., 3 (2016), pp. 796-802

Liu et al., 2016b Z. Liu, P. McNamara, D. Zitomer Biochar production and bio-oil upgrading by synergistic catalytic pyrolysis of wastewater biosolids and industrial wastes Proc. Water Environ. Fed. (9) (2016), pp. 3182-3187

Liu et al., 2017 Z. Liu, P.J. McNamara, D. Zitomer Autocatalytic pyrolysis of wastewater biosolids for product upgrading Environ. Sci. Technol., 15 (17) (2017), pp. 9808-9816

Liu et al., 2018 Z. Liu, S. Singer, Y. Tong, L. Kimbell, E. Anderson, M. Hughes, D. Zitomer, P. Mcnamara Characteristics and applications of biochars derived from wastewater solids Renew. Sust. Energ., 90 (2018), pp. 650-664

McNamara et al., 2014 P.J. McNamara, J.D. Koch, D.H. Zitomer Pyrolysis of wastewater biosolids: lab-scale experiments and modeling Proc. Water Environ. Fed., 2 (2014), pp. 1-14

McNamara et al., 2016 P. McNamara, J. Koch, Z. Liu, D.H. Zitomer Pyrolysis of dried wastewater biosolids can be energy positive Water Environ. Res., 88 (9) (2016), pp. 804-810

Rollinson and Oladejo, 2019 A.N. Rollinson, J.M. Oladejo Patented blunderings', efficiency awareness, and selfsustainability claims in the pyrolysis energy from waste sector Resour. Conserv. Recycl., 141 (October 2018) (2019), pp. 233-242

Ross et al., 2016 J.J. Ross, D.H. Zitomer, T.R. Miller, C.A. Weirich, P.J. Mcnamara Emerging investigators series: pyrolysis removes common microconstituents triclocarban, triclosan, and nonylphenol from biosolids Environ. Sci. Water Res. Technol., 2 (2016), pp. 282-289

Vesilind et al., 2002 P. Vesilind, W. WA, D. Reinhart Solid Waste Engineering CL Engineering (2002) 